\title{
Front Matter: Volume 9606
}

, "Front Matter: Volume 9606," Proc. SPIE 9606, Instruments, Methods, and Missions for Astrobiology XVII, 960601 (21 October 2015); doi:

10.1117/12.2217935

SPIE Event: SPIE Optical Engineering + Applications, 2015, San Diego, California, SPIE. United States 


\title{
PROCEEDINGS OF SPIE
}

\section{Instruments, Methods, and Missions for Astrobiology XVII}

\author{
Richard B. Hoover \\ Gilbert V. Levin \\ Alexei Yu. Rozanov \\ Nalin C. Wickramasinghe \\ Editors
}

9-11 August 2015

San Diego, California, United States

Sponsored and Published by

SPIE 
The papers in this volume were part of the technical conference cited on the cover and title page. Papers were selected and subject to review by the editors and conference program committee. Some conference presentations may not be available for publication. Additional papers and presentation recordings may be available online in the SPIE Digital Library at SPIEDigitallibrary.org.

The papers reflect the work and thoughts of the authors and are published herein as submitted. The publisher is not responsible for the validity of the information or for any outcomes resulting from reliance thereon.

Please use the following format to cite material from these proceedings:

Author(s), "Title of Paper," in Instruments, Methods, and Missions for Astrobiology XVII, edited by Richard B. Hoover, Gilbert V. Levin, Alexei Yu. Rozanov, Nalin C. Wickramasinghe, Proceedings of SPIE Vol. 9606 (SPIE, Bellingham, WA, 2015) Six-digit Article CID Number.

ISSN: 0277-786X

ISSN:1996-756X (electronic)

ISBN: 9781628417722

Published by

SPIE

P.O. Box 10, Bellingham, Washington 98227-0010 USA

Telephone +1 3606763290 (Pacific Time) · Fax +1 3606471445

SPIE.org

Copyright (C) 2015, Society of Photo-Optical Instrumentation Engineers.

Copying of material in this book for internal or personal use, or for the internal or personal use of specific clients, beyond the fair use provisions granted by the U.S. Copyright Law is authorized by SPIE subject to payment of copying fees. The Transactional Reporting Service base fee for this volume is $\$ 18.00$ per article (or portion thereof), which should be paid directly to the Copyright Clearance Center (CCC), 222 Rosewood Drive, Danvers, MA 01923. Payment may also be made electronically through CCC Online at copyright.com. Other copying for republication, resale, advertising or promotion, or any form of systematic or multiple reproduction of any material in this book is prohibited except with permission in writing from the publisher. The CCC fee code is 0277-786X/15/\$18.00.

Printed in the United States of America.

Publication of record for individual papers is online in the SPIE Digital Library.

\section{SPIE. DIGITAL}

Paper Numbering: Proceedings of SPIE follow an e-First publication model. A unique citation identifier (CID) number is assigned to each article at the time of publication. Utilization of CIDs allows articles to be fully citable as soon as they are published online, and connects the same identifier to all online and print versions of the publication. SPIE uses a six-digit CID article numbering system structured as follows:

- The first four digits correspond to the SPIE volume number.

- The last two digits indicate publication order within the volume using a Base 36 numbering system employing both numerals and letters. These two-number sets start with 00, 01, 02, 03, 04, 05, 06, 07, 08, 09, OA, OB ... 0Z, followed by 10-1Z, 20-2Z, etc. The CID Number appears on each page of the manuscript. 


\title{
Contents
}

\author{
vii Authors \\ ix Conference Committee
}

\section{SESSION 1 SIR FRED HOYLE CENTENARY TRIBUTE}

960602 The beginnings of life as a cosmic phenomenon [9606-1]

\section{SESSION 2 PHILOSOPHICAL CONSIDERATIONS OF ASTROBIOLOGY}

960603 Is life supernatural? (Invited Paper) [9606-2]

960604 Oparin's coacervates as an important milestone in chemical evolution (Invited Paper) [9606-3]

960605 Philosophy of astrobiology: some recent developments [9606-4]

\section{SESSION 3 EXOPLANETS, EXOMOONS AND ASTROBIOLOGY}

960609 The cosmic web and microwave background fossilize the first turbulent combustion [9606-42]

\section{SESSION 4 SETI}

$96060 \mathrm{~A}$ The search for extra-terrestrial intelligence: current status and future prospects (Invited Paper) [9606-8]

9606 OB The next phases of SETI@home [9606-9]

\section{SESSION 5 CHEMICAL EVOLUTION AND THE ORIGIN OF LIFE I}

9606 0C The case for a Martian origin for Earth life (Invited Paper) [9606-10]

9606 OD Prebiotic reactions in superheated water [9606-11]

$9606 \mathrm{OE}$ The bioinformatics of nucleotide sequence coding for proteins requiring metal coenzymes and proteins embedded with metals (Invited Paper) [9606-12] 
9606 OG Ribosome dynamics and the evolutionary history of ribosomes (Invited Paper) [9606-14]

$9606 \mathrm{OH} \quad$ Complexity of genetic sequences modified by horizontal gene transfer and degradedDNA uptake [9606-15]

\section{SESSION $7 \quad$ BIOMOLECULES AND MICROFOSSILS IN METEORITES}

$96060 \mathrm{~J} \mathrm{Possible} \mathrm{effects} \mathrm{of} \mathrm{diagenesis} \mathrm{on} \mathrm{the} \mathrm{stable} \mathrm{isotope} \mathrm{composition} \mathrm{of} \mathrm{amino} \mathrm{acids} \mathrm{in}$ carbonaceous meteorites (Invited Paper) [9606-17]

9606 OK Carbonaceous structures in the Tissint Martian Meteorite: evidence of a biogenetic origin (Invited Paper) [9606-18]

$9606 \mathrm{OL} \quad$ Chemical and structural composition of organic carbonaceous structures in Tissint: evidence for a biogenetic origin [9606-19]

9606 OM Microbiological investigation of two chondrite meteorites: Murchison and Polonnaruwa [9606-20]

\section{SESSION $8 \quad$ INSTRUMENTS AND METHODS TO SEARCH FOR EXTRATERRESTRIAL LIFE}

9606 ON Instruments and methods to search for extraterrestrial life [9606-21]

\section{SESSION $9 \quad$ ASTROBIOLOGY OF ICY MOONS, COMETS AND MARS I}

9606 OR Primordial comets: big bang nucleosynthesis, dark matter and life [9606-27]

9606 OS Arrhenius reconsidered: astrophysical jets and the spread of spores [9606-28]

9606 OT Hydro-gravitational-dynamics cosmology is crucial to astrobiology and the biological big bang at two million years [9606-29]

SESSION 10 ASTROBIOLOGY OF ICY MOONS, COMETS AND MARS II

9606 OV Evidence of ancient microbial activity on Mars [9606-32]

SESSION 11 MICROBIAL EXTREMOPHILES

9606 OW Microorganisms in extreme environments with a view to astrobiology in the outer solar system (Invited Paper) [9606-33]

9606 0X Molecular studies of anaerobic strains from Antarctica and their taxonomic identification [9606-34] 
9606 OY Search for the algorithm of genes distribution during the process of microbial evolution (Invited Paper) [9606-35]

\section{SESSION 12 EXTREMOPHILES, VIRUSES, AND THE ORIGIN OF LIFE}

960610 Bioinformatics comparison of sulfate-reducing metabolism nucleotide sequences [9606-37]

SESSION 13 POST-DEADLINE SESSION

9606 1A Wet comet model: Rosetta redux [9606-43]

9606 IR Ocean in Enceladus enhances the case for panspermia [9606-44] 
Proc. of SPIE Vol. $9606960601-6$

Downloaded From: https://www.spiedigitallibrary.org/conference-proceedings-of-spie on 26 Apr 2023 Terms of Use: https://www.spiedigitallibrary.org/terms-of-use 


\section{Authors}

Numbers in the index correspond to the last two digits of the six-digit citation identifier (CID) article numbering system used in Proceedings of SPIE. The first four digits reflect the volume number. Base 36 numbering is employed for the last two digits and indicates the order of articles within the volume. Numbers start with 00, 01, 02, 03, 04, 05, 06, 07, 08, 09, 0A, 0B...0Z, followed by 10-1Z, 20-2Z, etc.

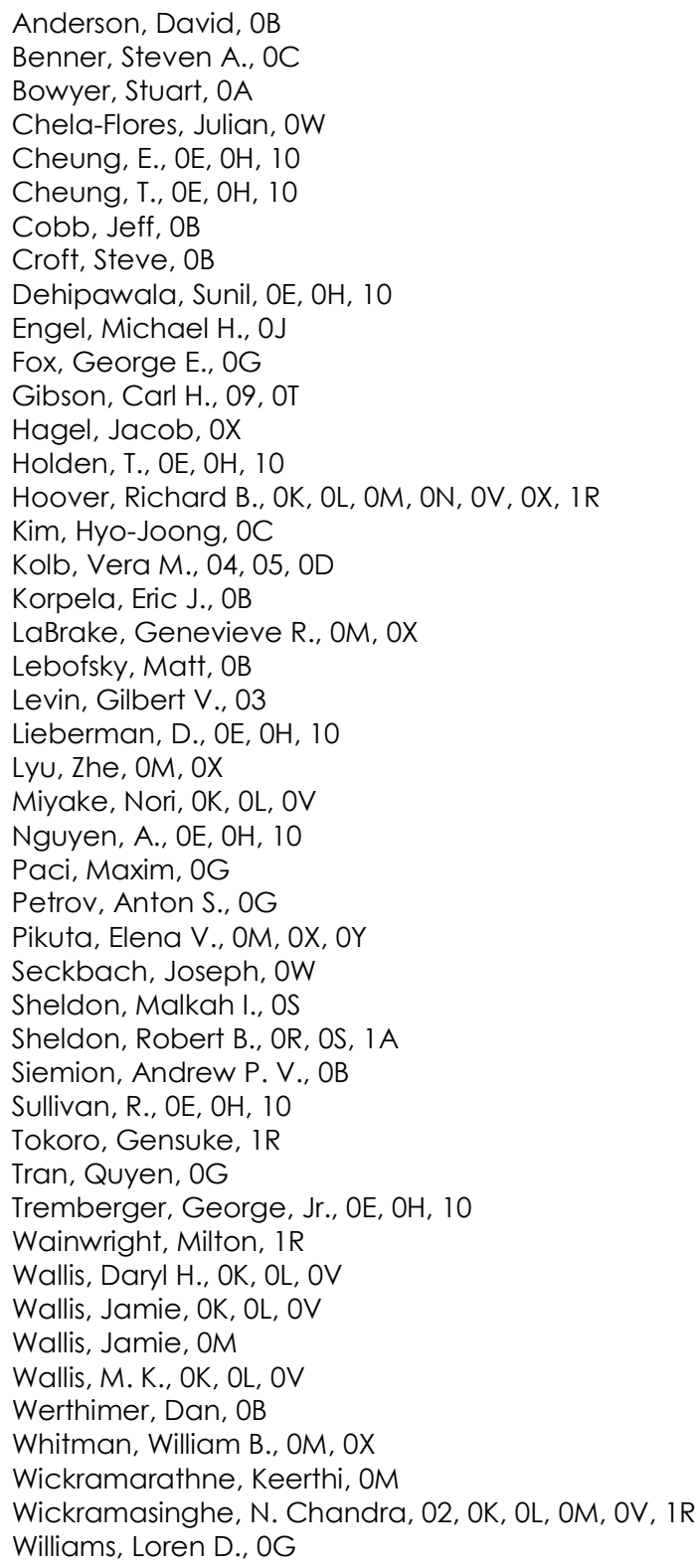


Proc. of SPIE Vol. $9606960601-8$

Downloaded From: https://www.spiedigitallibrary.org/conference-proceedings-of-spie on 26 Apr 2023 Terms of Use: https://www.spiedigitallibrary.org/terms-of-use 


\section{Conference Committee}

Program Track Chair

Oswald H. W. Siegmund, University of California, Berkeley

(United States)

Conference Chairs

Richard B. Hoover, Athens State University (United States) and Buckingham Center for Astrobiology (United Kingdom)

Gilbert V. Levin, Arizona State University (United States)

Alexei Yu. Rozanov, Joint Institute for Nuclear Research (Russian Federation)

Nalin C. Wickramasinghe, Buckingham Center for Astrobiology (United Kingdom)

Conference Program Committee

Stanley M. Awramik, University of California, Santa Barbara (United States)

Steven A. Benner, The Foundation For Applied Molecular Evolution (United States)

Stuart Bowyer, University of California, Berkeley (United States)

Nathalie A. Cabrol, SETI Institute (United States) and NASA Ames Research Center (United States)

Bin Chen, NASA Ames Research Center (United States)

Paul C. W. Davies, Arizona State University (United States)

Michael H. Engel, The University of Oklahoma (United States)

George E. Fox, University of Houston (United States)

Carl H. Gibson, University of California, San Diego (United States)

Brig Klyce, Astrobiology Research Trust (United States)

Vera M. Kolb, University of Wisconsin-Parkside (United States)

Eric J. Korpela, University of California, Berkeley (United States)

Rosaly Lopes, Jet Propulsion Laboratory (United States)

Prasanta K. Mukhopadhyay, Global Geoenergy Research Ltd.

(Canada)

Elena V. Pikuta, Athens State University (United States)

Joseph Seckbach, The Hebrew University of Jerusalem (Israel)

George Tremberger Jr., Queensborough Community College

(United States)

Luis Villarreal, University of California, Irvine (United States)

Daryl H. Wallis, Buckingham Center for Astrobiology (United Kingdom)

Jamie H. Wallis, Cardiff University (United Kingdom) 


\section{Session Chairs}

1 Sir Fred Hoyle Centenary Tribute

Richard B. Hoover, Athens State University (United States) and Buckingham Center for Astrobiology (United Kingdom)

2 Philosophical Considerations of Astrobiology

Richard B. Hoover, Athens State University (United States) and Buckingham Center for Astrobiology (United Kingdom)

3 Exoplanets, Exomoons and Astrobiology

Richard B. Hoover, Athens State University (United States) and Buckingham Center for Astrobiology (United Kingdom)

4 SETI

Vera M. Kolb, University of Wisconsin-Parkside (United States)

5 Chemical Evolution and the Origin of Life I

George E. Fox, University of Houston (United States)

6 Chemical Evolution and the Origin of Life II

Jamie H. Wallis, Cardiff University (United Kingdom)

7 Biomolecules and Microfossils in Meteorites

Robert B. Sheldon, NASA Marshall Space Flight Center (United States)

8 Instruments and Methods to Search for Extraterrestrial Life

Brig Klyce, Astrobiology Research Trust (United States)

9 Astrobiology of Icy Moons, Comets and Mars I

Joseph Seckbach, The Hebrew University of Jerusalem (Israel)

10 Astrobiology of Icy Moons, Comets and Mars II

Carl H. Gibson, University of California, San Diego (United States)

11 Microbial Extremophiles

Steven A. Benner, The Foundation For Applied Molecular Evolution (United States)

12 Extremophiles, Viruses, and the Origin of Life

Elena V. Pikuta, Athens State University (United States) 